\title{
Russell Body Lesions of the Colon: Case Report and Literature Review
}

\author{
W. Keith Tan ${ }^{1,2,3}$, Rachel Smith ${ }^{3}$, Anthony George ${ }^{3}$, Anita Gibbons ${ }^{1}$, Syed Shaukat ${ }^{1}$, Rizwan Kassam ${ }^{1}$ and Phil Roberts ${ }^{1}$ \\ Department of Gastroenterology and Hepatology, Hinchingbrooke Hospital, North West Anglia NHS Foundation Trust ${ }^{1}$, Huntingdon; MRC Cancer \\ Unit, University of Cambridge ${ }^{2}$, Cambridge; Department of Gastroenterology, Addenbrookes Hospital, Cambridge University NHS Foundation \\ Trust $^{3}$, Cambridge, United Kingdom
}

Russell bodies (RB) are rare manifestations within the lower gastrointestinal tract. To date, there are only three other reported cases of RB lesions of the colon; two were polyps, and the third was a case of a multifocal RB lesion of the gastrointestinal tract. This paper reports a case of a tubulovillous adenoma with RB of the sigmoid colon in a patient diagnosed incidentally as part of the UK National Health Service Bowel Cancer Screening Programme. A thorough hematological investigation is required to exclude hematological malignancies because of its association with plasma cell neoplasm. These lesions should undergo clonality analysis to exclude the monoclonal proliferation of plasma cells. Ideally, a bone marrow aspirate and investigations for amyloidosis should be performed to exclude underlying hematological malignancies. (Korean J Gastroenterol 2021;77:309-312)

Key Words: Polyps; Colon, sigmoid; Monoclonal; Multiple myeloma

\section{INTRODUCTION}

Russell bodies (RB) are eosinophilic, globular inclusions of immunoglobulins (Igs) found in dilated cisterns of the rough endoplasmic reticulum of mature plasma cells. These RB-containing plasma cells have been described as Mott cells. ${ }^{1}$ RB lesions within the colorectum are believed to be secondary to chronic mucosal inflammation and are extremely rare. ${ }^{2}$ To date, there are only three reports of such lesions occurring in the lower gastrointestinal (GI) tract. One report described a rectal polyp containing $\mathrm{RB}$ with monoclonal light chains. ${ }^{3}$ A second detailed a sigmoid polyp containing polyclonal light chains. ${ }^{4}$ The third was a case of multifocal 'RB-gastroenterocolitis' involving both the upper and lower gastrointestinal tract in a patient who had undergone a pancreas and renal transplant and subsequently developed post-transplant lymphoproliferative disease. ${ }^{5}$ This case report describes a further case of monoclonal light chain expression within a pedunculated polyp in the sigmoid colon with a review of the existing literature. This case report has been presented in accordance with the case report reporting checklist.

\section{CASE REPORT}

As part of the National Health Service Bowel Cancer Screening Programme, a 77-year-old man underwent CT colonography after a positive fecal occult blood test. Colonography revealed extensive sigmoid diverticular disease and a large $25 \mathrm{~mm}$ pedunculated polyp in the mid-sigmoid colon, which was confirmed on flexible sigmoidoscopy and subsequently removed using a hot snare polypectomy (Fig. 1). The procedure was uneventful, and he recovered without any sequelae.

The histology of the retrieved polyp revealed a tubulovillous adenoma with low-grade dysplasia. Focal ulceration was ob-

Received February 20, 2021. Revised April 13, 2021. Accepted April 13, 2021.

(C) This is an open access article distributed under the terms of the Creative Commons Attribution Non-Commercial License (http://creativecommons.org/licenses/ by-nc/4.0) which permits unrestricted non-commercial use, distribution, and reproduction in any medium, provided the original work is properly cited. Copyright (c) 2021. Korean Society of Gastroenterology.

Correspondence to: W. Keith Tan, Department of Gastroenterology, Hinchingbrooke Hospital, Parkway Hinchingbrooke, Huntingdon, PE29 6NT, United Kingdom. Tel: +44-1480416416, E-mail: weikeithtan@gmail.com, ORCID: https://orcid.org/0000-0001-9013-2311

Financial support: None. Conflict of interest: None. 
served, and the lamina propria appeared significantly distended with numerous plasma cells containing large hyaline globules consistent with RB. He was referred to a regional tertiary center for a specialist opinion because of concerns that these changes might represent a possible plasma cell neoplasm.

A specialist review by a histopathologist confirmed the prominent plasma cell infiltrate in the lamina propria, with some plasma cells showing a classical morphology whilst others contained prominent cytoplasmic Ig globules consistent with RB inclusions (Fig. 2). Immunohistochemistry revealed no loss of CD79a expression, or aberrant CD66, CD20, CyclinD1 or CD117 expression in any of the plasma cell components. The smaller plasma cells appeared polytypic, even though those containing RB showed stronger staining with lambda light chains. The stains for the heavy chains were

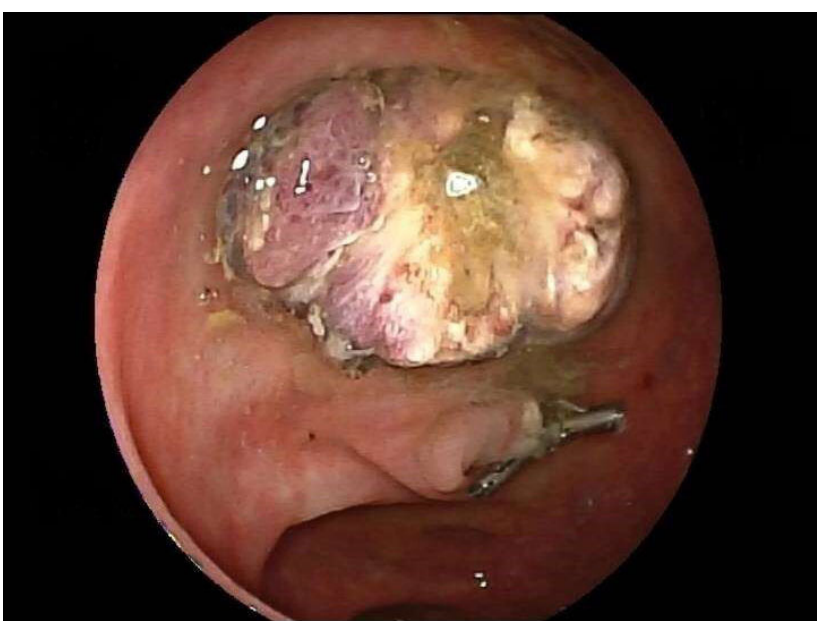

Fig. 1. Endoscopic view of a sigmoid colon tubulovillous adenoma containing Russell bodies. Post-polypectomy appearance of the sigmoid polyp with the application of endoclips to prevent bleeding due to the patient needing to recommence anticoagulation. non-contributory, and there were no significant $\mathrm{B}$ or $\mathrm{T}$ cell infiltrates.

Subsequent clonality analysis using a polymerase chain reaction showed monoclonal IgG rearrangements on a polyclonal background. The presence of a monoclonal IgG raises the suspicion of myeloma. Accordingly, the patient was referred for a hematology opinion.

The full blood count and biochemistry were normal. Serum-free light chains, kappa to lambda ratio, and serum paraprotein were also normal. Urinalysis showed non-proteinuric chronic kidney disease stage 3. A bone marrow trephine biopsy revealed a mildly hypercellular bone marrow with no increase in plasma cells and no evidence of amyloid deposits on Congo red staining. The CT skeletal survey was negative for lytic lesions. Echocardiography did not reveal any features of cardiac amyloidosis.

The confirmatory tests for myeloma were negative. Hence, the patient was referred to the National Amyloid Centre in London to exclude systemic amyloidosis. Serum Amyloid $\mathrm{P}$ Component (SAP) scintigraphy showed no visceral amyloid deposits and no evidence of systemic amyloidosis. The patient did not require specific treatment and has remained under annual review. Three years later, the patient remains well.

Written informed consent was obtained from the patient for publication of this case report and all accompanying images. Ethical approval was not required.

\section{DISCUSSION}

RB were originally described by the Scottish pathologist William Russell in 1890; he called the lesions 'fuchsine bodies' because of their staining pattern and suggested that they were budding fungi that could be associated with cancer
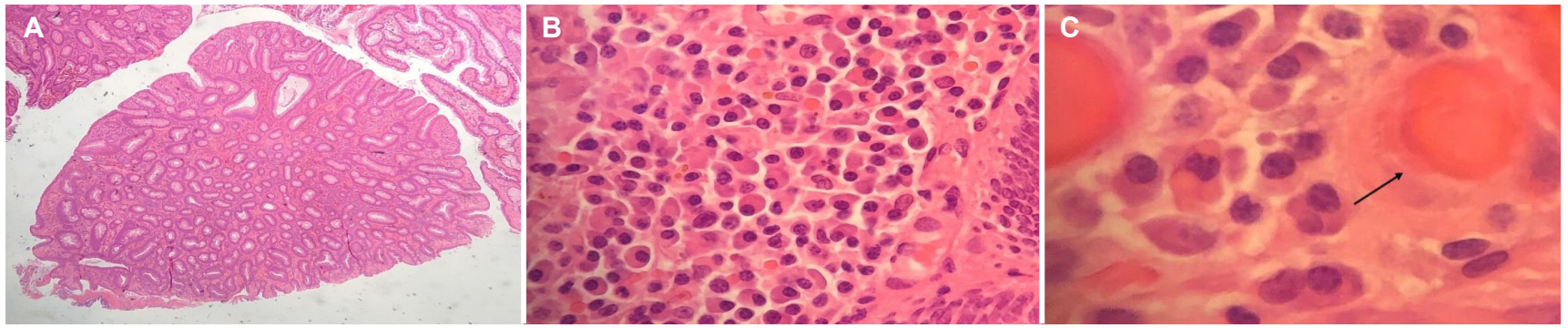

Fig. 2. Microscopic view of tubulovillous adenoma containing Russell bodies. (A) $\times 40$ magnification (hematoxylin and eosin staining) view of the polyp with histology showing tubulovillous adenoma. (B) $\times 400$ magnification (hematoxylin and eosin staining) view of the lamina propria showing abundant plasma cell infiltrate. (C) $\times 600$ magnification (hematoxylin and eosin staining) view showing individual plasma cells with the black arrow denoting a Russell body-containing plasma cell, i.e. Mott cell. 
development. 6 In 1905, Frederick Mott described plasma cells in the brains of monkeys with trypanosomiasis, which were full of inclusions that were similar to the fuchsine bodies described by Russell. ${ }^{1}$ Consequently, these cells were referred to as Mott cells. ${ }^{7}$ In 1998, Tazawa and Tsutsumi described the first case of an RB-containing lesion in the upper Gl tract in a patient with Helicobacter Pylori infection. ${ }^{8}$ Since then, multiple reports of RB lesions of the Gl tract have been published, with most cases found predominantly in the stomach. ${ }^{5}$ Russell body lesions are unusual findings that indicate an exaggerated inflammatory response with the resultant expansion of the IgG-producing plasma cell population. ${ }^{2}$

Colonic lesions containing RB are extremely rare, and to the best of the authors' knowledge, only three such cases have been reported. Brink et al. ${ }^{3}$ reported the first case of an RB colonic polyp with histology revealing a tubulovillous adenoma with high-grade dysplasia and the associated expression of monoclonal light chain Mott cells. Coates et al. ${ }^{4}$ reported the second case of RB colonic polyp within the sigmoid colon with associated erythema and histology confirming the reactive inflammatory changes within a hyperplastic polyp. As in the present case, the polyp occurred in a patient with a background of severe diverticular disease. Only one case of multifocal 'RB-gastroenterocolitis' that occurred in an immunosuppressed patient who underwent a pancreas and renal transplant has been reported. This patient had biopsy confirmation of RB in the gastric, duodenum, terminal ileum and colon and subsequently developed post-transplant lymphoproliferative disorder involving her cervical lymph nodes. ${ }^{5}$
The present case is only the third reported case of a colonic polyp containing RB (the fourth case of RB lesions of the colon ever reported) with the associated expression of monoclonal light chains (Table 1). Unlike other precancerous polyps where surveillance strategies have been well established, the exceedingly low prevalence of RB colonic polyps makes it difficult to devise any evidence-based management strategy for this rare condition. Of the two other patients with RB found on polyp histopathology, neither underwent an evaluation for an underlying plasma cell neoplasm. ${ }^{3,4}$ Given the association between RB lesions and multiple myeloma, ${ }^{9,10}$ it would be reasonable to evaluate these patients for underlying hematological neoplasm. The histopathology of the polyp should also undergo thorough scrutiny and clonality analysis with polymerase chain reaction to exclude monoclonal plasma cell populations. In cases where the histopathological diagnosis is uncertain, referral to a tertiary center for a second opinion by a specialist hematopathologist is recommended. In this case, clonality analysis revealed a clonal IgG rearrangement, thereby raising the suspicion for myeloma, even though subsequent investigations were negative.

Owing to the association between myeloma and amyloid light-chain ( $A L)$ amyloidosis, our patients was referred to the National Centre for Amyloidosis in London, a quaternary institution that pioneered SAP-scintigraphy for systemic amyloidosis. SAP are of glycoproteins that are found in all types of amyloid. SAP-scintigraphy has been developed as a nuclear-medicine technology utilizing SAP radiolabeled with iodine-123 ${ }^{123}$ I-SAP), which, when injected, localizes rapidly and

Table 1. Case Reports of RB Lesions of the Lower Gastrointestinal Tract

\begin{tabular}{|c|c|c|c|c|c|c|}
\hline Study & Age/sex & $\begin{array}{l}\text { Anatomic } \\
\text { location }\end{array}$ & Endoscopic features & Pathology & Histologic features & Additional analysis \\
\hline $\begin{array}{l}\text { Brink et al. } \\
(1999)^{3}\end{array}$ & $53 / F$ & Rectum & Rectal polyp & $\begin{array}{l}\text { Tubulovillous } \\
\text { adenoma with HGD }\end{array}$ & $\begin{array}{l}\text { Dense focal infiltrates of } \\
\text { RB-containing plasma } \\
\text { cells }\end{array}$ & $\begin{array}{l}\text { Monoclonal IgG for k light } \\
\text { chains } \\
\text { Negative IgA within } \\
\text { dysplastic epithelium }\end{array}$ \\
\hline $\begin{array}{l}\text { Muthukumarana } \\
\text { et al. }(2015)^{5}\end{array}$ & $44 / F$ & Multifocal & $\begin{array}{l}\text { Erythematous gastric } \\
\text { body, duodenal ulcer, } \\
\text { normal ileum and colon }\end{array}$ & $\begin{array}{l}\text { Gastric mucosa with } \\
\text { patchy IM }\end{array}$ & $\begin{array}{l}\text { Lymphoplasmacytic } \\
\text { infiltrate in the lamina } \\
\text { propria }\end{array}$ & $\begin{array}{l}\text { CD138+ } \\
\text { Polyclonal }\end{array}$ \\
\hline $\begin{array}{l}\text { Coates et al. } \\
(2017)^{4}\end{array}$ & $62 / \mathrm{M}$ & Sigmoid & Sigmoid polyp & $\begin{array}{l}\text { Hyperplastic with } \\
\text { inflammatory } \\
\text { infiltrate }\end{array}$ & $\begin{array}{l}\text { Expanded lamina propria } \\
\text { with Mott cells infiltrate }\end{array}$ & $\begin{array}{l}\text { CD138+ and CD79a+ } \\
\text { Polyclonal }\end{array}$ \\
\hline $\begin{array}{l}\text { Tan et al. } \\
\text { (present case) }\end{array}$ & $77 / \mathrm{M}$ & Sigmoid & Sigmoid polyp & $\begin{array}{l}\text { Tubulovillous } \\
\text { adenoma with LGD }\end{array}$ & $\begin{array}{l}\text { Prominent polytypic } \\
\text { plasma cell infiltrate in } \\
\text { the lamina propria }\end{array}$ & $\begin{array}{l}\text { Monoclonal lgG light chains } \\
\text { on a polyclonal } \\
\text { background }\end{array}$ \\
\hline
\end{tabular}

RB, Russell body; HGD, high-grade dysplasia; IM, intestinal metaplasia; LGD, low-grade dysplasia; IgG, immunoglobulin G; IgA, immunoglobulin A. 
binds specifically to amyloid deposits, allowing the identification of visceral amyloid deposits with a $\geq 90 \%$ sensitivity of diagnosing AL-amyloidosis. ${ }^{11,12}$ In the present patient, SAP-scintigraphy did not reveal any evidence of systemic amyloidosis. Although we appreciate that many institutions may have limited access to SAP-scintigraphy, if available this test should be performed to rule out systemic amyloidosis. A flexible sigmoidoscopy with a rectal biopsy, abdominal subcutaneous fat aspiration or minor salivary gland biopsies are alternative approaches if SAP-scintigraphy is unavailable. ${ }^{13}$

Owing to the lack of understanding of the natural history of RB colonic lesions, the present patient has remained under annual hematology surveillance to monitor for the possible development of plasma cell neoplasms or lymphoproliferative disorders, as observed in the case reported by Muthukumarana et al. ${ }^{5}$ To date, three years after the initial polypectomy, the patient has remained well. Among the existing literature, there have not been any reported cases of recurrence of polyps containing RB following polypectomy. Therefore, surveillance colonoscopy should be based on the highest histopathological grade of dysplasia of the polyp and should follow the national polyp surveillance guidelines. ${ }^{14}$

\section{REFERENCES}

1. Mott FW. Observations on the brains of men and animals infected with various forms of trypanosomes. Preliminary note. Proceedings of the Royal Society of London. Series B, Containing Papers of a Biological Character 1905;76:235-242.

2. Reinhard H, Karamchandani DM. Russell bodies and russell body inflammatory polyp in the colorectum: a review of clin- icopathologic features. Biomed Res Int 2018;2018:2845291.

3. Brink T, Wagner B, Gebbers JO. Monoclonal plasma and Mott cells in a rectal adenoma. Histopathology 1999;34:81-82.

4. Coates RF, Ferrentino N, Yang MX. Russell body inflammatory polyp. Int J Surg Pathol 2017;25:94-96.

5. Muthukumarana V, Segura S, O'Brien M, Siddiqui R, El-Fanek H. "Russell body gastroenterocolitis" in a posttransplant patient: a case report and review of literature. Int J Surg Pathol 2015; 23:667-672.

6. Russell W. An address on a characteristic organism of cancer. $\mathrm{Br}$ Med J 1890;2:1356-1360.

7. Bain BJ. Russell bodies and Mott cells. Am J Hematol 2009; 84:516.

8. Tazawa K, Tsutsumi Y. Localized accumulation of Russell body-containing plasma cells in gastric mucosa with Helicobacter pylori infection: 'Russell body gastritis'. Pathol Int 1998;48: 242-244.

9. Martín-Noya A, Ríos-Herranz E, Rafel-Ribas E. Multiple myeloma with numerous intranuclear Russell bodies. Haematologica 1999;84:179-180.

10. van Gammeren AJ, Alcala LS, Smolders M, Boersma RS. Numerous Russell bodies and Dutcher bodies in multiple myeloma. Br J Haematol 2015;170:743.

11. Sachchithanantham S, Wechalekar AD. Imaging in systemic amyloidosis. Br Med Bull 2013;107:41-56.

12. Hazenberg BP, van Rijswijk MH, Piers DA, et al. Diagnostic performance of 123l-labeled serum amyloid $P$ component scintigraphy in patients with amyloidosis. Am J Med 2006;119:355. e15-355.e3.55E24.

13. Wisniowski B, Wechalekar A. Confirming the diagnosis of amyloidosis. Acta Haematol 2020;143:312-321.

14. Rutter MD, East J, Rees CJ, et al. British Society of Gastroenterology/Association of Coloproctology of Great Britain and Ireland/Public Health England post-polypectomy and post-colorectal cancer resection surveillance guidelines. Gut 020;69:201-223. 